\title{
OSTEOSARCOMA HAS NOT BECOME ATTENTION TO SOCIETY PROFILE OF OSTEOSARCOMA PATIENTS AT DR. SOETOMO GENERAL HOSPITAL SURABAYA “A RETROSPECTIVE STUDY”
}

\author{
Ferdiansyah Mahyudin $^{1 *}$, Mouli Edward ${ }^{1}$, Muhammad Hardian Basuki ${ }^{1}$, Yunus Abdul \\ Bari $^{2}$, Yesa Suwandani ${ }^{3}$ \\ ${ }^{1}$ Department of Orthopaedic and Traumatology, Faculty of Medicine, Universitas Airlangga / \\ Dr Soetomo Hospital, Surabaya \\ ${ }^{2}$ Department of Orthopaedic and Traumatology, Faculty of Medicine, Universitas Airlangga / \\ Airlangga Hospital, Surabaya \\ ${ }^{3}$ Resident in Department of Orthopaedic and Traumatology, Faculty of Medicine, Universitas \\ Airlangga / Dr Soetomo General Hospital, Surabaya \\ *Corresponding Author: Ferdiansyah Mahyudin, Department of Orthopaedic and \\ Traumatology, Faculty of Medicine, Universitas Airlangga / Dr Soetomo Hospital, Surabaya, \\ J1. Mayjen Prof. Dr. Moestopo 6-7, Surabaya 60286 \\ E-mail: ferdyortho@yahoo.com
}

\begin{abstract}
ABSTRAK
Latar belakang: Osteosarkoma merupakan neoplasma tulang primer yang paling banyak ditemukan di masyarakat, namun evaluasi kasus osteosarkoma di RSUD Dr. Soetomo belum diperbaharui sejak 1995.

Tujuan: Penelitian ini bertujuan untuk mengetahui karakteristik pasien osteosarkoma beserta terapi yang diberikan di RSUD Dr. Soetomo pada tahun 2007-2016 sehingga dapat membantu merepresentasikan karakteristik pasien osteosarkoma di RSUD Dr. Soetomo

Metode: Rancangan penelitian adalah retrospektif deskriptif penderita Osteosarkoma di RSUD Dr. Soetomo Surabaya pada periode 2007-2016. Data didapatkan dari Tumor Database Departemen Orthopaedi dan Traumatologi RSUD Dr. Soetomo Surabaya kemudian dilakukan penelusuran lebih lanjut dengan menghubungi pasien melalui telepon maupun kunjungan ke rumah.

Hasil: Pasien osteosarkoma terbanyak didapatkan pada tahun 2015, sedangkan paling sedikit pada tahun 2008, dengan tren jumlah pasien yang terus meningkat. Mayoritas pasien datang dalam kondisi lanjut. Terapi yang paling sering dilakukan pada pasien adalah amputasi baik disertai kemoterapi ataupun tidak. Survival rate pada pasien baik pada 1 tahun, 2 tahun, maupun 5 tahun lebih rendah dibandingkan angka dari sumber lain. Penyebab terbanyak mortalitas adalah akibat metastasis tumor.
\end{abstract}

Kesimpulan: Kesadaran masyarakat tentang tanda-tanda dan bahaya kanker masih rendah, kemauan untuk mengutamakan pengobatan medis masih kurang. Hal ini mengakibatkan rendahnya angka deteksi dini osteosarkoma dan tingginya kasus metastasis akibat penanganan awal yang tidak tepat. Sosialisasi lebih lanjut dan peningkatan kewaspadaan dari petugas kesehatan akan kecurigaan osteosarkoma diperlukan untuk memperbaiki keberhasilan penanganan serta angka survival pada pasien.

Kata kunci: osteosarkoma, profil, Indonesia, survival rate

\begin{abstract}
Background: Osteosarcoma is the most common bone neoplasm found in the community but evaluation osteosarcoma cases in RSUD Dr. Soetomo has not been updated since 1995.

Purpose: This study o osteosarcoma patient characteristic as well as therapy at Dr. Soetomo General Hospital in 2007 to 2016. It expects to show survival rates of osteosarcoma patient, so
\end{abstract}


it can be a reference for searching the problems in the treatment of osteosarcoma cases and helps to decide treatment for osteosarcoma.

Research Methods: Descriptive retrospective study, conducted on osteosarcoma patients at Dr. Soetomo General Hospital during 2007-2016 periods. Data were obtained from Ortho tumor patient database, and contacting them by phone or home visit.

Results: Osteosarcoma patients was found mostly in 2015, while the least in 2008, with trend increasing by time. Majority of the patients came with advanced stage. Osteosarcoma treated mostly by amputation, either with or without chemotherapy. The survival rate in the first, second, or the fifth year was found lower than other references. Most common cause of mortality was the metastasis.

Conclusion: Awareness of the society about the cancer sign of cancer and desire to use medical treatment as a priority is still low. This causes a low early detection rate of osteosarcoma and a high rate of metastatic cases because of inappropriate early treatment. Further socialization and increased awareness of medics about the suspicion of osteosarcoma are needed to improve the success rate of treatment as well as the survival rate.

Keywords: osteosarkoma, profile, Indonesia, survival rate

\section{PENDAHULUAN}

Osteosarkoma merupakan neoplasma tulang yang didiagnosa berdasarkan pemeriksaan histologi terhadap produksi osteoid berhubungan dengan malignant mesenchymal cells. Osetosarkoma umumnya adalah tumor yang agresif dan cenderung bermetastasis secara dini.

Di Indonesia, berdasarkan Riset Dasar Kesehatan 2013 didapatkan prevalensi penyakit kanker sebesar 1,4 per mil (\%o). ${ }^{1}$ Odds ratio tumor tulang adalah $4.6^{2}$ sedangkan insiden tumor tulang ganas di Indonesia didapatkan sebesar $1,6 \%$ dari seluruh jenis tumor ganas pada manusia, ${ }^{3}$ dengan kecenderungan meningkatnya insiden tumor tulang setiap tahunnya. Insiden tumor tulang di RS Ciptomangunkusumo sebesar $1,2 \%$, dengan insiden tumor tulang ganas sebesar 1,3\%. Berdasarkan data sistem informasi rumah sakit tahun 2005, osteosarkoma termasuk dalam lima besar kasus kanker pada usia 1-17 tahun. ${ }^{4}$ Pada evaluasi profil tumor tulang pada anak di RS Ciptomangunkusumo tahun 1995-2004, didapatkan 73,7\% kasus merupakan kasus osteosarkoma. ${ }^{5}$ Pada tahun 1991-1995, di RSUD Dr. Soetomo didapatkan tumor ganas tulang sebanyak 373 kasus, dengan tumor ganas tulang primer sebanyak 183 kasus. Perbandingan pria: wanita $1.4: 1$ dan jumlah kasus primer 44 kasus per tahun, terutama osteosarkoma sebesar $62,4 \%$ kasus. ${ }^{6}$

Berdasarkan data WHO, osteosarkoma adalah tumor tulang primer paling umum dengan estimasi insiden 45/1.000.000 per tahun. ${ }^{7}$ Di Eropa, 
Artikel Penelitian

Vol 7 No. 1, April 2018

ISSN 2460-8742

http://journal.unair.ac.id/ORTHO@journal-orthopaedi-and-traumatology-surabaya-media-104.html

didapatkan insiden 0,2-3/100.000 per tahun dalam kelompok usia 15-19 tahun. ${ }^{8}$ Angka 2-year survival rate di Taiwan didapatkan sebesar 46,9\%, dengan 5-year survival rate sebesar $37,5 \%$. $^{9}$

Sebelum adanya perkembangan kemoterapi, amputasi dan disartikulasi merupakan terapi utama osteosarkoma dengan angka 5-year overall survival hanya $10-20 \%$. Perkembangan teknik operasi dan advanced musculoskeletal imaging, serta teknik limb salvage surgery meningkatkan survival rates menjadi $80 \% .^{10}$

Penelitian ini bertujuan untuk mengetahui karakteristik pasien osteosarkoma beserta terapi yang diberikan di RSUD Dr. Soetomo pada tahun 2007 sampai 2016, dengan harapan dapat membantu merepresentasikan karakteristik pasien osteosarkoma di RSUD Dr. Soetomo serta membantu dalam menentukan manajemen terbaik bagi pasien osteosarkoma.

\section{METODOLOGI PENELITIAN}

Rancangan penelitian adalah retrospektif deskriptif pada penderita Osteosarkoma di RSUD Dr. Soetomo Surabaya pada periode 2007-2016. Kriteria inklusi pada penelitian ini adalah pasien yang didiagnosa osteosarkoma di
Departemen Orthopaedi dan Traumatologi RSUD Dr Soetomo Surabaya pada periode 2007-2016. Kriteria eksklusi pada penelitian ini adalah: (1)pasien yang dengan pemeriksaan lanjutan (biopsi) mengalami perubahan diagnosa menjadi selain osteosarkoma, (2) pasien yang tidak tercatat tindakan yang dilakukan, (3) tidak dapat dilakukan follow up baik dengan telepon maupun kunjungan ke rumah dan juga (4) pasien yang telah meninggal sebelum diambil keputusan rencana tindakan.

Variabel yang dievaluasi adalah jenis kelamin, usia pasien saat pertama kali datang ke poli Orthopaedi dan Traumatologi RSUD Dr. Soetomo, stage dari osteosarkoma pasien, ukuran dari tumor primer saat pasien pertama kali mencari penanganan medis, riwayat manipulasi/pengobatan alternatif sebelum pasien mencari penanganan medis, jenis tindakan medis yang telah dilakukan, riwayat pemberian kemoterapi baik sebagai adjuvan maupun sebagai terapi, serta kondisi pasien (hidup/meninggal) saat evaluasi.

Penelitian dilakukan di RSUD Dr. Soetomo Surabaya pada periode Agustus 2016. Data dicari dari Tumor Database Departemen Orthopaedi dan Traumatologi RSUD Dr. Soetomo 
http://journal.unair.ac.id/ORTHO@journal-orthopaedi-and-traumatology-surabaya-media-104.html

Surabaya, kemudian dilakukan penelusuran lebih lanjut dengan menghubungi pasien melalui telepon maupun kunjungan ke rumah. Pasien pada penelitian ini diberi informasi mengenai latar belakang dan tujuan penelitian serta bebas memilih untuk ikut berpartisipasi atau tidak. Sebelum berpartisipasi pada penelitian ini, pasien diharuskan menandatangani formulir persetujuan.

\section{HASIL DAN PEMBAHASAN}

Pasien terbanyak didapatkan pada tahun 2015, sedangkan paling sedikit pada tahun 2008. Terdapat tren peningkatan jumlah total pasien secara keseluruhan dari tahun ke tahun berdasarkan analisa tren linear sebagaimana yang terlihat pada Gambar 1 berikut:

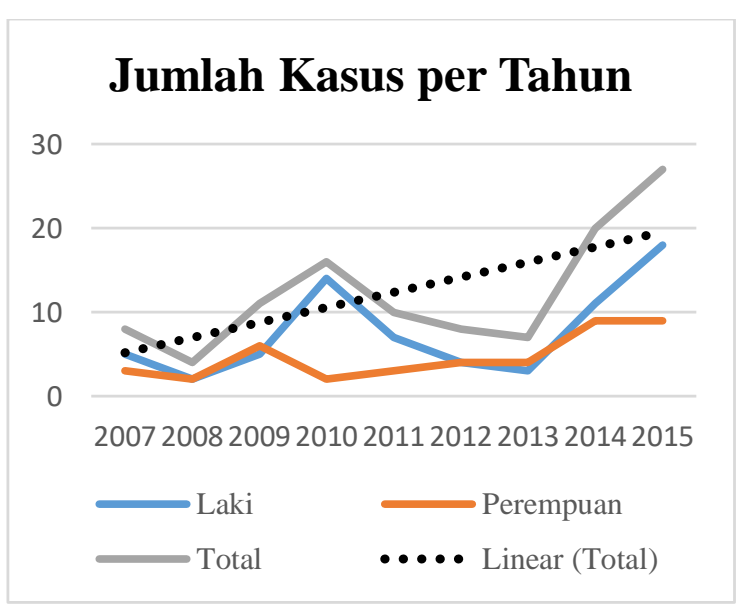

Gambar 1. Grafik distribusi kasus osteosarkoma setiap tahun
Dari 122 pasien yang terdiagnosa awal dengan osteosarkoma, 28 pasien tidak dapat dievaluasi lebih lanjut karena data tidak lengkap atau karena pasien drop out sebelum diagnosa pasti ditegakkan.

Jumlah total pasien laki laki lebih banyak hampir setiap tahunnya dibandingkan jumlah pasien wanita. Rata-rata jumlah pasien pria per tahun merupakan $61 \%$ dibandingkan jumlah rata rata pasien wanita per tahun (39\%).

Distribusi tumor terbanyak pada femur (40\%), diikuti dengan tibia (32\%), fibula $(11 \%)$, humerus $(11 \%)$, serta letak lain $(6 \%)$. Dari femur sendiri, distal femur memiliki proporsi terbanyak (84\%). Pada tibia proximal proporsi $(83 \%)$, fibula proximal $(90 \%)$, humerus proximal (100\%).

Usia pasien osteosarkoma terbanyak (73\%) 11-20 tahun baik pada laki laki maupun perempuan, dengan proporsi pasien laki laki keseluruhan (63\%) lebih banyak dibandingkan jumlah pasien perempuan $(37 \%)$.

Tumor staging terbanyak stage IIB $(61 \%)$ adalah dengan usia terbanyak pada staging masing-masing 11-20 tahun (67\%) untuk stage IIA, juga usia 11-20 tahun (74\%) untuk stage IIB, dan usia 1120 tahun (75\%) untuk stage III (Tabel 1). 
Artikel Penelitian

Vol 7 No. 1, April 2018

ISSN 2460-8742

http://journal.unair.ac.id/ORTHO@journal-orthopaedi-and-traumatology-surabaya-media-104.html

Tabel 1. Distribusi pasien berdasarkan usia dan staging

\begin{tabular}{|c|c|c|c|}
\hline $\begin{array}{c}\text { Kelompok umur } \\
\text { (tahun) }\end{array}$ & \multicolumn{3}{|c|}{ Staging } \\
\cline { 2 - 4 } & II A & II B & III \\
\hline $0-10$ & 0 & 1 & 0 \\
$11-20$ & 6 & 42 & 21 \\
$21-30$ & 1 & 7 & 3 \\
$31-40$ & 2 & 3 & 1 \\
$41-50$ & 0 & 3 & 0 \\
$51-60$ & 0 & 1 & 2 \\
$>60$ & 0 & 0 & 1 \\
\hline Total & 9 & 57 & 28 \\
\hline
\end{tabular}

Didapatkan usia terbanyak dimana pasien didapatkan adanya osteosarkoma adalah pada usia 16 tahun, baik pada laki laki maupun perempuan. Data tersebut dapat dilihat pada Tabel 2 berikut:

Tabel 2. Rerata dan median dari jenis kelamin serta grade tumor pasien

\begin{tabular}{|c|c|c|c|c|c|c|}
\hline \multirow{2}{*}{$\begin{array}{c}\text { Usia } \\
\text { tahun })\end{array}$} & \multicolumn{2}{|c|}{ Jenis Kelamin } & \multicolumn{3}{c|}{ Grade } \\
\cline { 2 - 7 } & L & P & Total & IIA & IIB & III \\
\hline Mean & 19.38 & 20.34 & 19.75 & 21.36 & 18.64 & 20.88 \\
\hline Median & 16 & 16 & 16 & 19 & 16 & 17 \\
\hline
\end{tabular}

Berdasarkan staging, stage IIA didapatkan paling sering pada usia yang lebih tua dibanding pada stage IIB dan stage III, walaupun masih dalam rentang kelompok usia yang sama (11-20 tahun).

$$
\text { Mayoritas pasien }(68 \%)
$$
menjalani terapi manipulasi (pijat, terapi alternatif) sebelum mencari penanganan medis, dengan proporsi dari pasien laki laki (78\%) yang melakukan manipulasi lebih besar dibanding pasien perempuan $(50 \%)$.

Pada pasien yang menjalani terapi manipulasi, distribusi terbanyak berada pada stage IIB baik laki laki (48\%) maupun perempuan (58\%). Demikian pula halnya pada pasien yang tidak melakukan terapi manipulasi terbanyak berada pada stage IIB baik laki laki (27\%) maupun perempuan $(57 \%)$

Secara proporsi, jumlah pasien yang melakukan terapi manipulasi pada grup staging tertinggi pada laki-laki stage III (90\%) sedangkan pada wanita pada stage III $(62,5 \%)$.

Baik pada pasien laki laki (58\%) maupun perempuan (54\%) tindakan tersering yang dilakukan adalah amputasi/limb ablation pada laki-laki yang mana terbanyak pada stage IIB (64\%) dan pada wanita tersering pada stage III (75\%).

Terapi kemoterapi diberikan pada $68 \%$ pasien laki laki, dengan distribusi terbanyak pada stage IIB (61\%), serta pada $62 \%$ pasien perempuan, dengan distribusi terbanyak juga pada stage IIB (67\%).

Untuk evaluasi survival rate, dari 122 pasien yang terdata, hanya 30 pasien yang dapat dilakukan follow up, sehingga 
survival rate dievaluasi dengan data yang diperoleh dari 30 pasien ini.

Pada pasien-pasien tersebut 1year survival rate adalah sebesar 50\%, dengan perbedaan 1-year survival rate pada pria $(58 \%)$ dan wanita $(33 \%)$ yang dievaluasi. Berdasarkan staging, 1-year survival rate dari grup III memiliki survival rate paling rendah (sebesar 0), diikuti dari grup IIB sebesar $47 \%$ yang memiliki jumlah sampel yang terbanyak (83\%) dibandingkan dengan stage IIA (6\%) dan stage III (12\%).

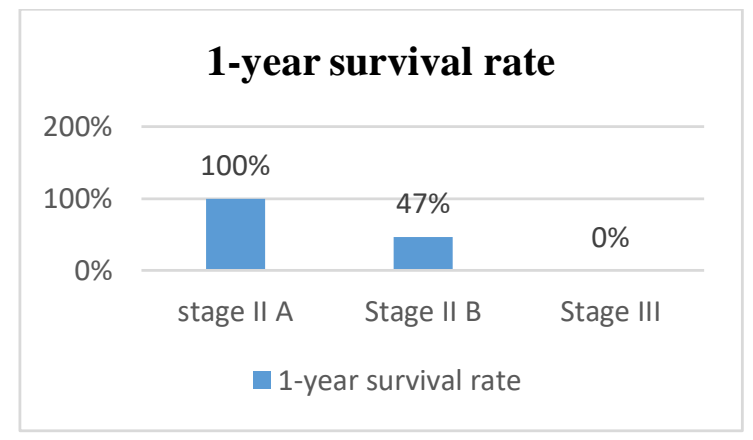

Gambar 2. Diagram distribusi 1-year survival rate berdasarkan staging

Mayoritas pasien yang meninggal adalah pasien stage IIB (78\% dari pasien yang meninggal), dengan proporsi $53 \%$ dari pasien stage IIB meninggal, tetapi stage III yang hanya merupakan $22 \%$ dari pasien yang meninggal memiliki proporsi pasien meninggal dari stage III sebesar $100 \%$.
Mayoritas pasien yang meninggal memiliki riwayat pengobatan kemoterapi dengan tindakan operatif (56\%).

Didapatkan 2-year survival rate sebesar 33\%, dengan perbedaan 2-year survival rate pada pria (38\%) dan wanita (25\%) yang dievaluasi. Berdasarkan staging, 2-year survival rate dari stage IIA dan III memiliki survival rate paling rendah (sebesar 0\%), tetapi memiliki jumlah sampel yang terendah pula, yaitu $8 \%$ baik untuk stage IIA maupun stage III, dibandingkan dengan stage IIB (83\%) sebagaimana terlihat pada Gambar 3 berikut:

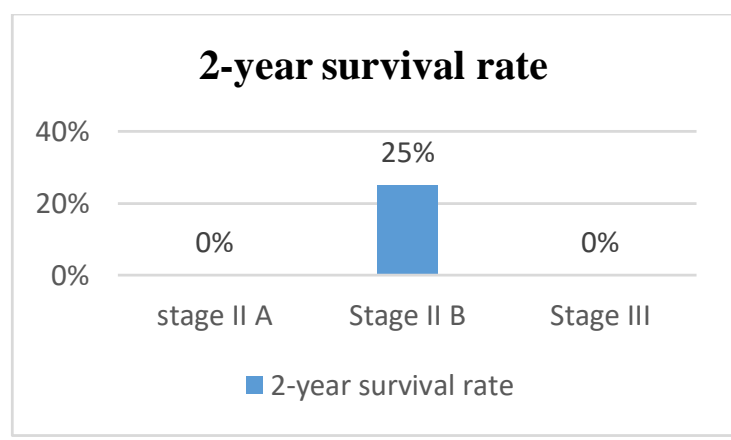

Gambar 3. Diagram distribusi 2-year survival rate berdasarkan staging

Dari pasien yang meninggal dalam evaluasi 2-year survival rate, $62,5 \%$ adalah pasien laki laki. Penyebab kematian terbanyak adalah karena tumor primer atau karena metastasis. Proporsi keduanya sama yaitu $37,5 \%$. Pasien yang meninggal kebanyakan tidak memiliki riwayat dilakukan manipulasi pemijatan sebelum mencari terapi medis $(62,5 \%)$. 
Artikel Penelitian

Vol 7 No. 1, April 2018

ISSN 2460-8742

http://journal.unair.ac.id/ORTHO@journal-orthopaedi-and-traumatology-surabaya-media-104.html

Mayoritas pasien yang meninggal adalah pasien stage IIB (75\% dari pasien yang meninggal), dengan proporsi $60 \%$ dari pasien stage IIB meninggal, tetapi stage III yang hanya merupakan 13\% dari pasien yang meninggal memiliki proporsi pasien meninggal dari stage III sebesar $100 \%$. Mayoritas pasien yang meninggal memiliki riwayat pengobatan kemoterapi dengan tindakan operatif sebesar 37,5\%.

Hanya 3 pasien yang dapat dievaluasi sampai saat ini dengan diagnosa telah ditegakkan sejak sedikitnya 5 tahun sebelum dilakukan evaluasi, seluruhnya adalah laki-laki. Awal keluhan tumor paling sering muncul pada usia 15 tahun, dengan stage didapatkan seluruhnya merupakan stage IIB (83\%). Pasien yang dievaluasi terbanyak dilakukan gabungan kemoterapi dengan terapi operatif (66\%).

Dari pasien yang dievaluasi, $67 \%$ meninggal dalam 5 tahun sejak ditegakkan diagnosa, dengan kasus meninggal seluruhnya adalah yang telah dilakukan terapi kemoterapi dengan terapi operatif (100\%). Five-year survival rate didapatkan sebesar 33\%, dengan seluruhnya merupakan pasien dengan stage IIB.

Dari pasien yang meninggal dalam evaluasi 5-year survival rate, seluruhnya dalah pasien laki laki.
Penyebab kematian yang terbanyak didapatkan sama banyaknya karena adanya metastasis dengan karena efek kemoterapi (50\%). Pasien yang meninggal semuanya memiliki riwayat dilakukan manipulasi pemijatan sebelum mencari terapi medis $(100 \%)$.

Seluruh pasien yang meninggal adalah pasien stage IIB, dengan proporsi $67 \%$ dari pasien stage IIB meninggal (Gambar 4). Mayoritas pasien yang meninggal memiliki riwayat pengobatan kemoterapi dengan tindakan operatif $(50 \%)$.

Didapatkan 1 pasien yang putus pengobatan yang meninggal pada stage IIB.

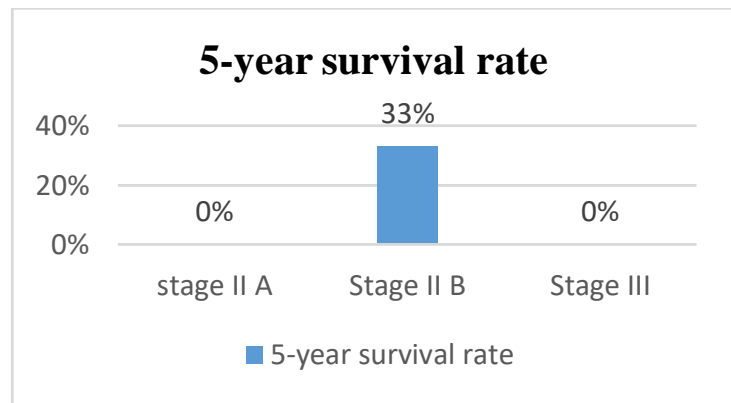

Gambar 4. Diagram distribusi 5-year survival rate berdasarkan staging

Pada evaluasi survival rate, didapatkan hasil survival rate tertinggi pada evaluasi 1-year survival rate, baik pada laki-laki, perempuan, maupun secara keseluruhan. Serta didapatkan survival rate dari pasien laki laki yang lebih tinggi dari survival rate pasien 
wanita, dengan pada evaluasi 5-year survival rate tidak didapatkan pasien wanita yang dapat dievaluasi.

Selain pada evaluasi 5-year, survival rate dari pasien yang telah menjalani manipulasi didapatkan lebih tinggi dibandingkan survival rate pada masa evaluasi yang sama.

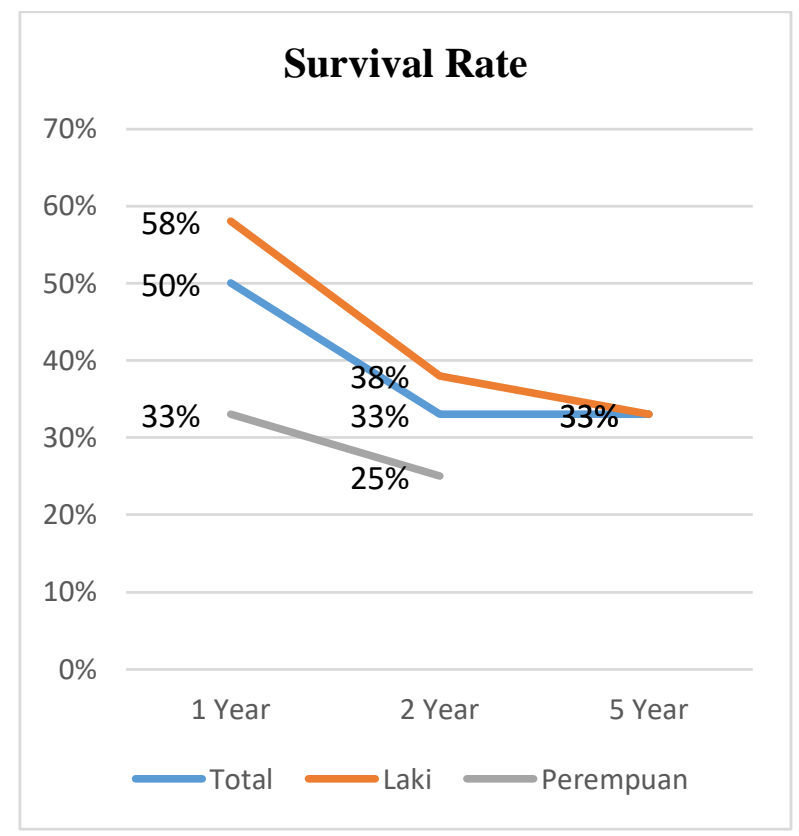

Gambar 5. Survival rate 1, 2, 5 tahun pada pasien osteosarkoma

Rata-rata terdapat 12,2 pasien baru setiap tahunnya di RSUD Dr. Soetomo, dengan karakteristik epidemiologi kasus osteosarkoma yang datang ke RSUD Dr. Soetomo sesuai dengan epidemiologi osteosarkoma pada umumnya. ${ }^{11}$

Jumlah pasien terdiagnosa 3 tahun terakhir berada di atas rata rata yang didapatkan, menunjukkan adanya peningkatan kasus osteosarkoma yang terdiagnosa. Hal ini dapat disebabkan karena meningkatnya kesadaran masyarakat tentang tumor, lebih terjangkaunya pelayanan medis ke berbagai lapisan masyarakat, atau memang disebabkan penyebab lain yang meningkatkan insiden kasus osteosarkoma.

Jumlah kasus osteosarkoma yang terdiagnosa terus meningkat dari tahun ke tahun, akan tetapi pasien yang datang seringkali sudah dalam tahap lanjut, dengan ukuran yang sudah besar, atau telah melakukan terapi manipulasi sebelumnya. Fakta bahwa pasien baru mencari pengobatan setelah kondisi tumor sudah lanjut ini menunjukkan adanya permasalahan yang perlu diperbaiki. Jumlah kasus yang ditangani dari tahun ke tahun cenderung meningkat, sehingga nampaknya permasalahan lebih terletak pada kesadaran masyarakat yang rendah tentang pentingnya penanganan medis awal pada kasus tumor. ${ }^{6}$

Tindakan medis paling sering yang dilakukan adalah amputasi/limb ablation, pada laki laki tersering pada kasus stage IIB, dan pada wanita tersering pada kasus stage III. Terapi kemoterapi juga diberikan pada kebanyakan pasien osteosarkoma, dengan 
distribusi terbanyak pada stage IIB. Penanganan ini sudah sesuai dengan literatur dimana terapi pada osteosarkoma konvensional adalah operatif dengan disertai terapi adjuvan, dimana tindakan operasi dimaksudkan untuk melakukan kontrol lokal, dapat berupa limb salvage atau limb saving, maupun berupa limb ablation atau amputasi. ${ }^{12}$

Pada penelitian ini angka survival rate lebih rendah dibandingkan dengan studi lain di luar negeri (Gambar 6). ${ }^{13}$ Survival rate yang lebih buruk pada 1year, 2-year dan 5-year dapat disebabkan beberapa hal. Kecenderungan dari pasien untuk mencari pengobatan medis setelah kondisi lanjut (nampak dari mayoritas pasien dengan stage IIB dan ukuran tumor $>8 \mathrm{~cm}$ ) mengakibatkan rendahnya jumlah sampel kasus dengan stage awal yang semestinya memiliki survival rate yang lebih tinggi. Penyebab lain adalah rendahnya jumlah sampel yang dapat dihubungi untuk dapat dilakukan evaluasi. Kecenderungan dari pasien untuk mencari pengobatan alternatif manipulatif sebelum mencari pengobatan medis juga diperkirakan berpengaruh terhadap hasil survival rate. Selain karena tingginya kasus lanjut yang datang untuk berobat, ada kemungkinan perlu dilakukannya pembaharuan regimen kemoterapi pada pasien osteosarkoma.
Angka survival rate dari tahun ke tahun cenderung menurun, akan tetapi evaluasi pada sampel yang lebih luas dengan jangka waktu lebih lama diperlukan untuk mendapatkan hasil evaluasi yang lebih representatif.

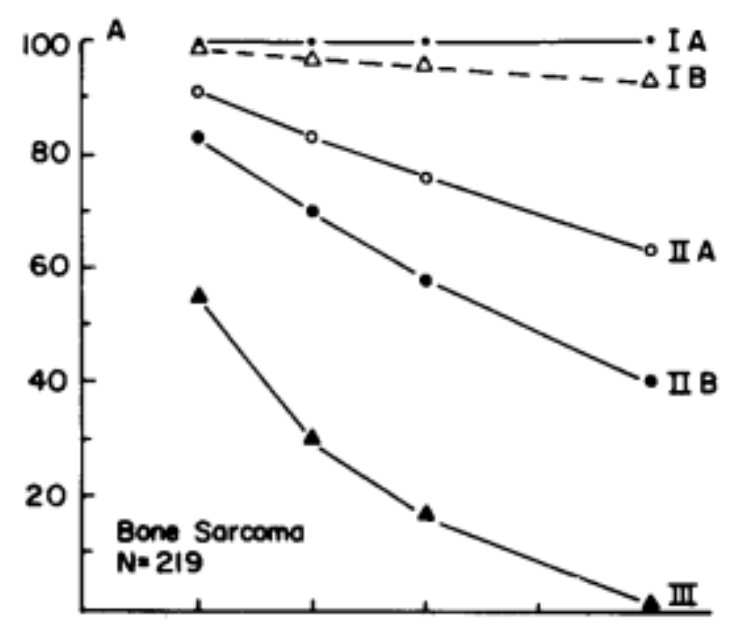

Gambar 6. Survival rate setiap tahun hingga 5 tahun pada pasien osteosarkoma berdasarkan stage ${ }^{13}$

\section{KESIMPULAN DAN SARAN}

Jumlah kasus osteosarkoma yang terdiagnosa terus meningkat dari tahun ke tahun, akan tetapi pasien yang datang seringkali sudah dalam tahap lanjut, dengan ukuran yang sudah besar, atau telah melakukan terapi manipulasi sebelumnya.

Evaluasi 5 tahun hanya dapat mengevaluasi 3 pasien, dikarenakan kesulitan dalam follow up subjek penelitian.

Didapatkan angka survival rate yang lebih rendah pada pasien yang 
dievaluasi di RSUD Dr. Soetomo dibandingkan dengan studi lain di luar negeri. Selain karena tingginya kasus lanjut yang datang untuk berobat, ada kemungkinan perlu dilakukannya perbaharuan regimen kemoterapi pada pasien osteosarkoma.

Penyebab utama kematian pada kasus osteosarkoma yang sedang menjalani terapi adalah metastasis. Penting untuk meningkatkan screening dan monitoring tidak hanya pada pasien baru, tetapi juga pada pasien yang sedang menjalani terapi untuk segera tertangani bila terjadi metastasis.

Untuk studi selanjutnya, perlu lebih ditekankan mengenai kedisiplinan dan ketelitian dalam mencatat dan mengorganisir segala info kontak serta hasil pemeriksaan dari pasien yang ditangani, agar sampel yang didapatkan dapat lebih representatif.

Kesadaran dari masyarakat tentang tanda tanda dan bahaya dari kanker masih rendah, serta kemauan untuk mengutamakan pengobatan medis masih kurang, yang berakibat rendahnya angka deteksi dini dari osteosarkoma, dan tingginya kasus metastasis akibat penanganan awal yang tidak tepat. Sosialisasi lebih lanjut dan peningkatan kewaspadaan dari petugas kesehatan akan kecurigaan osteosarkoma diperlukan untuk memperbaiki keberhasilan penanganan serta angka survival pada pasien

\section{REFERENSI}

1. Kesehatan BP. Riset Kesehatan Dasar 2013. Jakarta: KEMENTERIAN KESEHATAN RI; 2013.

2. Oemiati R, Rahajeng E, Kristanto AY. Prevalensi Tumor dan Beberapa Faktor yang Mempengaruhinya di Indonesia. Jakarta: Badan Penelitian dan Pengembangan Kesehatan; 2007.

3. Norahmawati E. Fine Needle Aspiration Biopsy Mempunyai Peranan Penting dan Akurasi Tinggi Sebagai Metode Diagnostik Preoperatif Tumor Tulang. Jurnal Kedokteran Brawijaya. 2009;XXV(2):77-82.

4. Publik PK. 2009 [Available from: http://www.depkes.go.id/article/vie w/166/aktivitas-fisik-dan-dietseimbang-mencegah-kanker.html.

5. Hutagalung EU, Kamal AF. Profile of Bone Cancer In Children in Cipto Mangunkusumo Hospital 19952004. Jakarta: Faculty of Medicine University of Indonesia; 2005.

6. Abdurrahman E, Lunardhi J, Widjanarko B, Ashariati A, Erawati 
D. Penanganan Terpadu Tumor Muskuloskeletal (1st ed.). Surabaya: Airlangga University Press; 1998.

7. Laux CJ, Berzaczy G, Weber M, Lang S, Dominkus M, Windhager R, et al. Tumour response of osteosarcoma to neoadjuvant chemotheraphy evaluated by magnetic resonance imaging as prognostic factor for outcome. International Orthopaedics (SICOT). 2014:1-8.

8. Luetke A, Meyers PA, Lewis I, Juergens H. Osteosarcoma treatment - Where do we stand? A state of the art review. Cancer Treatment Review. 2013:1-10.

9. Poon K-B, Chien S-H, Lin G-T, Wang G-J. Impact of National Health Insurance on the Survival Rate of Patients with Osteosarcoma In Taiwan: Review of 74 Patients. The Kaohsiung Journal of Medical Sciences. 2004;20(5 (May 2004)):230-4.

10. Han G, Bi WZ, Xu M, Jia JP, Wang Y. Amputation Versus Limb-Salvage Surgery in Patients with Osteosarcoma: A Meta Analysis. World Journal of Surgery. 2016:112.
11. Ottaviani G, Jaffe N. The Epidemiologi of Osteosarcoma. Cancer Treat Res. 2009;152:3-13.

12. Hutagalung EU, Gumay $S$, Budyatmoko B. Neoplasma Tulang: Diagnosis dan terapi (1st ed.). Jakarta: PT Galaxy Puspa Mega; 2005.

13. Enneking WF, Spanier SS, Goodman MA. Surgical staging of sarcomas. Clinical Orthopaedics and Related Research. 1980;153:106-20. 